\title{
KUTATÁS-MÓDSZERTANI TRENDEK A MARKETINGBEN
}

Az üzleti élet globalizálódása, a technológiai fejlődés által nyújtott új eszközök részben új lehetőségeket, részben új feladatokat, elvárásokat jelentenek mind a tudományos, mind a gyakorlati marketingkutatás számára. Változnak az adatfelvétel módszerei, a fogyasztók attitüdjének és magatartásának változásával a primer kutatás módszerei között is hangsúlyeltolódás következik be, megnő a megfigyeléses, a kísérleti vizsgálatok szerepe. A kvalitatív és kvantitatív kutatás közötti határvonal is elmosódik, mindkét kutatási módszertanban új típusú módszerek jelennek meg és terjednek el. A nagy adatbázisok, a Big data lehetôségeit is integrálnia kell a marketingkutatásnak és az adatelemzésnek. A tanulmány a jelenlegi változások, valamint a jövő́beli szcenáriók felvázolására is kísérletet tesz. ${ }^{1}$

Kulcsszavak: marketingkutatási módszerek, kvalitatív módszerek, kvantitatív módszerek, adatbázis-marketing

Az üzleti és a marketingkörnyezetben bekövetkezett sok és gyors változás következtében a marketingkutatás is számos új kihívással szembesül. Jelen dolgozatban elsősorban a marketingkutatás megváltozott feltételrendszerét és az ebből következő új lehetőségeket és problémákat elemezzük, összpontosítva a tudományos kutatásra jellemző kérdésekre, valamint a kihívásokra adható válaszokra.

A vállalati környezet legfontosabb változásai a nemzetközi, globalizálódott piacon folyó tovább élesedő verseny, amely a szereplő́k számára elengedhetetlenné teszi a nagyon gyors technológiai változások eredményeinek alkalmazását, a piacorientáció további erősödését, ehhez az információk hatékonyabb hasznosításának szükségességét és lehetôségét. Az információk egyre nagyobb mennyiségben állnak rendelkezésre, megjelennek a nagy adatbázisok, amelyek lehetôvé teszik a database marketing kialakulását, amelyekben a fogyasztók egyes tranzakcióinak adatait a szekunder információkkal összekapcsolják. Az adatbázis-marketing egyéni szinten teszi lehetővé a hatékony célzást (Palmquist - Ketola, 1999), valamint sok esetben lehetôvé teszi, hogy az adatbázisban rendelkezésre álló, elsősorban vásárlási szokást mutató adatot a primer kutatásban nem szükséges megkérdezni.

A technológiai fejlődés a fogyasztóval való viszonyt is átalakítja, ami a partneri viszony kialakítását jelenti, magában foglalva több új, a magatartásra hatással levő jelenséget, mint az empowerment, a co-creation, ezek a jelenségek a gyakorlati piackutatási módszereket is befolyásolják. A technológiai fejlődés olyan új eszközök használatát teszi lehetôvé a marketingkutatásban, mint az elektronikus eszközök, az internet, a mobiltelefon és az összes, a digitális kort már jellemző eszköz, amelyek megjelenése gyors ütemben folytatódik és ezek fokozott hozzáférhetőségére és alkalmazására a jövőben is számítani kell. Ezek az eszközök jelentős változásokat jelentenek a kutatási módszertanban, valamint az eredmények felhasználásában, értékelésében is.

A vállalati szerkezet átalakul a laposabb szervezetek irányába, amikor a döntéshozók egyre közelebb kerülnek az elemzőkhöz, és a marketingkutatás szerepe egyre kevésbé a passzív háttérelemzés, egyre nagyobb szerepet kap az insight-megfogalmazás, amely a vállalati marketinggel és a vállalati stratégiai döntéshozatallal való aktív együttmúködéshez vezethet.

\section{A marketingkutatás tudományos és gyakorlati jellege - a tudományos kutatási módszertan fejlódése}

A marketingkutatás fejlődésében, tendenciáiban vizsgálhatjuk a tudományos kutatásban és a gyakorlati kutatásban érvényesüló, illetve várható tendenciákat.

A tudományos kutatást és a gyakorlati kutatást gyakran a szerint különböztetik meg, hogy mi a kutatás célja, vagy ki végzi a kutatást, vagy milyen módszertani eszköztárat használnak a kutatás során. Hivatkoznánk 
Brinberg és Hirschman 1986-beli meghatározására, miszerint „az akadémiai, tudományos orientációjú kutatás koncepciókra összpontosít és a koncepciók közötti összefüggésekre (gyakran alapkutatásnak hívják, és az általánosíthatóságot és a konceptualizálást társítják hozzá). A gyakorlati kutatás pedig elsősorban jelenségekre összpontosít, amely lehet egy rendszer, egy szervezet, vagy a valódi világból származó események halmaza (többféle elnevezés használatos, mint alkalmazott, tanácsadói vagy problémaorientált kutatás és döntően pragmatikus jelentőséget tulajdonítanak neki). A tudományos kutatási orientációnak nagyon fontos szándéka a tudományos szigorúság maximális érvényesítése (a mérőszámok és eljárások precíz és ellenőrzött használata) a koncepciók halmazának vizsgálatakor."

A tudományos igényú kutatásban is megfigyelhetôk, bár más súllyal, mindazok a változások, amelyek a gyakorlati kutatást jellemzik, ugyanakkor olyan tendenciákat is tapasztalhatunk, amelyek a gyakorlatban talán kevésbé hangsúlyosak.

A tudományos igényú és a gyakorlati kutatás közös jellemzője a szekunder források felértékelődése, döntően a nagymennyiségú adat rendelkezésre állása, hozzáférhetősége következtében. Az adattárházak lehetővé teszik a nagy adatbázisok létrejöttét és elemzését (Jackson - Wang, 1984). Az adatbázis-marketing alkalmazása mind a B2B, mind a B2C marketingben növekszik (Bacon, 1999). Ma is jellemzó és a továbbiakban is folytatódó tendenciaként növekedni fog az adatbázisok alkalmazása: a szegmentációban, a célcsoportképzésben, az újtermék-fejlesztésben, a keresztértékesítési lehetőségek feltárásában, a fogyasztói lemorzsolódás elemzésében és előrejelzésében, a fogyasztói magatartás változásainak előrejelzésében, az elégedettségi és a tracking kutatások alapján leszúrhető minták feltárásában. A tudományos kutatási módszertannak részben ezekhez a feladatokhoz felhasználható módszertani fejlesztéseket kell kidolgoznia, részben pedig a konkrét jelenségek és az általánosíthatóság követelményeinek új típusú kihívásainak kell megfelelnie.

A kutatási módszertan fejlődésének egyik fontos jellemzője, hogy a hagyományos kvalitatív és kvantitatív kutatás között gyakran elmosódik a határvonal, a jelen tárgyalásban mégis szétválasztjuk a két nagy csoport tárgyalását a tendenciák jobb megvilágíthatósága érdekében.

\section{A kvalitatív kutatás}

A tudományos kutatásban megnőtt, átalakult a kvalitatív kutatás szerepe, új módszerek jelennek meg, illetve a már használt módszerek intenzívebb alkalmazására kerül sor.

Ezt a fejlődést az az igény hívta életre, amely a fogyasztói magatartás megismerését a korábbinál sokkal inkább a miért-re, az attitüdre, a viselkedési mintákon belül is a különösre, az egyedire helyezte, ami azt is jelenti, fóleg a gyakorlati kutatásokban, hogy minél több jellemzőt, minél teljesebb képet lehessen nyerni az egyéni fogyasztó viselkedéséről és annak mozgatórugóiról. A tudományos kutatásra is hatott a gyakorlatnak ez a megnövekedett igénye, és az, hogy a gyakorlati piackutatás is nagyon sok egyéni és csoportos interjút végez, amiból a gyártók és forgalmazók egyre több információt kapnak akár kisebb fogyasztói csoportok, egyének magatartásáról is. A tudományos kutatásban is megjelennek azok a módszerek, amelyek a megfigyelési egység, az egyéni vagy szervezeti fogyasztó, vásárló magatartásának megfigyelésére összpontosítva, minőségi jellegú adatgyújtést végeznek, amelyet elemeznek és következtetéseket vonnak le. Ezek a módszerek induktív jellegúek, amelyben epizódok, események, egyéni jellemzők összegyuujtésével, elemzésével keletkeznek, feltevések, konstrukciók, szemben azzal a deduktív jellegú konstrukcióalkotással, amikor valamilyen általánosítható összefüggésrendszerből nyeri a konkrét esetre vonatkoztatható hipotéziseket és konstrukciókat. Az elméletalkotó, elméletet generáló kvalitatív módszertanban megkülönböztetett szerepet kapott a grounded theory (Glaser - Strauss, 1967) és az esettanulmány-módszer (Yin, 1984; Eisenhardt, 1989, 1991). Az esettanulmány módszerét az IMP Group kutatói is gyakran alkalmazzák, klasszikus példákat találhatunk például Hakansson (1982) munkásságában.

Mindkét módszertan alkalmazása a nemzetközi szakirodalomban is vitatott, legalább is, ami az alkalmazási körülményeket, illetve leginkább a belólük levonható következtetéseket illeti. A viták egyik sarkpontja az ún. elméletalkotás, a theory construction. A klasszikus paradigmák a kvalitatív és a kvantitatív paradigma, amelyben a kvalitatív módszerrel elsősorban feltáró jellegú, elméletalkotó kutatás végezhető, míg a kvantitatív módszertan leíró jellegú, a feltárt konstrukciót teszteli, verifikálja és megerősíti (Deshpande, 1983). Az elméletalkotás és tesztelés elfogadott, kevésbé vitatott módja a mérési és strukturális modellezés, amelyben a modell alapja az elméleti konstrukció, a mérhetó és a látens, nem mérhető változók közötti kapcsolatokat leíró hipotézis, amelyet kvantitatív módon, statisztikai mintában gyújtött empirikus adatokkal lehet tesztelni. Az elméleti konstrukcióknak ilyen módon való tesztelése és bizonyítása általánosan elfogadott és bár vannak vitatott kérdések, az nem tartozik közéjük, hogy alkalmas-e ez a módszer hipotézistesztelésre.

Az esettanulmány-módszernél alkalmazott adatgyújtési technikák: a dokumentumok elemzése (szekunder kutatás), interjúk készítése, amelyet gyakran résztvevő-megfigyeléssel is kiegészítenek. A kvalitatív kutatások mintavételi módszereként gyakran alkalmaz- 
zák az ún. elméleti mintavételi módszert, amely nem statisztikai jellegú és a vizsgált jelenség feltárását minél inkább alátámasztó módon történik a mintaelemek kiválasztása (Kröber et al., 2008).

Az esettanulmány-módszernél gyakran felmerül az érvényességi probléma kérdése. Az elméletalkotásnál mind az érvényességet, mind a megbízhatóságot, valamint az általánosíthatóságot vizsgálni kell. Fontos rögzíteni, hogy nem az a probléma, ha olyan kutatási módszert használunk, amelynek eredménye kevésbé megbízható vagy általánosítható, hanem ha ezt nem megfelelóen ismeri fel a kutató. Ebben a témakörben az egyik legtöbbet idézett szerző Eisenhardt, aki cikkeiben (Eisenhardt, 1989, 1991) elemzi, hogy az esettanulmány-módszernél például milyen típusú és számú esettanulmány ajánlható ahhoz, hogy az eredményeknél induktív elméletalkotásról beszélni lehessen (4 és 10 közötti olyan esettanulmány, amelyben az interjú és a szekunder kutatás mellett rendszerint kvantitatív típusú kutatást is végeznek). A szakirodalomban folyó éles vitát mutatja az is, hogy erről az ajánlásról is vita folyik, amelyben érvként hangzik el, hogy az egyes esettanulmányok is rendszerint több kis alesetből állnak, és hogy az egyes esetekből is természetesen levonhatók következtetések, még ha a konstrukcióalkotási lehetóség korlátozott is. Az esettanulmány-módszer hidat képez az induktív típusú, a gazdag kvalitatív jellegú adatból konstrukciót képező kutatás és a deduktív típusú, az elméleti konstrukciót építo és tesztelő kutatás között.

A fogyasztói magatartás változásaira való válaszként több olyan kutatási módszer vagy kutatási szemlélet is megjelent, amelyből két olyan módszert említünk, amelyek a magyar kutatásokra is hatással vannak.

Az egyik gyakran alkalmazott módszer, amely a keletkező új fogyasztói magatartási kérdéseket vizsgálja, a netnográfia. A netnográfia olyan kvalitatív kutatási módszer, amely adaptálja az etnográfiai kutatási technikákat az on-line közösségek kultúrájának vizsgálatához (Kozinets, 2002). A módszer alkalmazására példa a bioélelmiszerek piacán végzett kutatás, amelyben a netnográfiát feltáró jellegú, kvalitatív kutatásként használták, amelyben a bio-élelmiszerekkel kapcsolatos fórumok elemzése alapján tárták fel a fogyasztók attitüdjét (Horváth - Mitev, 2015).

A másik lényeges és új típusú irány a posztmodern kutatás, amely a nemzetközi szakirodalomban figyelemre méltó jelentőségúnek mondható. A hazai szakirodalomban Fojtik $(1999,2006)$, valamint Horváth és Mitev (2015) foglalkoznak az irányzattal, illetve folytatnak ezzel a módszertannal kutatásokat. A posztmodern kutatás a meghatározó „mainstream” kutatási irányzatokkal való szembenállást képviseli. A kutatási irányzat képviselői gyakran érvelnek azzal, hogy a modern marketing teljes eszköztára, a fogyasztói tár- sadalom, a vásárlás, a reklámok, az üzletek /bevásárló központok, a pozicionálás hozza létre a posztmodern jelenséget (Brown, 1995). A posztmodern mindenekelőtt kulturális jelenség, míg elutasítja a modernitást, mint a társadalmi rend meghatározásának egyetlen vezérelvét, a posztmodern az alábbiak megvalósítására törekszik: az esztétikai megközelítés visszaállítása, az emberi élet nyelvi és szimbolikus aspektusaira kiemelt figyelmet tulajdonítva, kiemeli a vizualitás és a látványosság szerepét, felismeri a szubjektív tapasztalatok jelentőségét.

A posztmodern az irányzat hívei szerint is nehezen definiálható, de hitük szerint olyan kutatási módszer, amely a jelenlegi körülmények között élő világ feltárására, a technikai és gazdasági-társadalmi megváltozott körülmények között élő fogyasztó magatartásának kutatására alkalmasabb eszköz, mint a hagyományos kutatási módszerek.

A kvalitatív kutatási eredmények feldolgozásában az új szoftverek megjelenése megvalósította a szöveges eredmények, a tartalmak olyan elemzését, amely részben a szövegben rejlő struktúrákat képes feltárni, részben bizonyos szintú kvantifikációval való jellemzést és elemzést tesz lehetóvé. A CATPAC (Moore et al., 1995), az Atlas /ti.(SCOLARI, 2000), valamint az NVivo (Richards, 1999) szofisztikált kódolást tesznek lehetôvé szövegek, hangfelvételek és videók esetében. Ezek az eszközök elósegítik az elméletalkotást azáltal, hogy konceptuális modelleket segítenek kidolgozni. Az alkalmazásuk növekvő tendenciája várható a jövőben is.

\section{A megfigyeléses és kísérleti módszerek}

Mind a kvalitatív, mind a kvantitatív kutatásban új tendencia, hogy a primer kutatásban a megkérdezés mellett egyre nagyobb hangsúlyt kap a megfigyelés és a kísérlet, mint a fogyasztóról gyújthető valós információk egyik eszköze. Ez egybecseng azzal a változással, ami a technikai lehetóségek következtében a regisztrálható típusú információk körének kibővülésével jár együtt, amely lehetôvé teszi olyan információk valós adatokon alapuló gyuujtését, amelyról korábban a megkérdezés keretében informálódtunk.

A kísérleti módszertan terjedését elősegíti a technikai eszközök elérhetősége, a kísérlet könnyen megvalósítható on-line körülmények között, akár valós környezetben, akár laboratóriumi körülmények között. A kísérletet és a megfigyelést olyan technikai eszközök is segítik, mint a szemkamera és a hozzá tartozó kiértékelő szoftverek. A megfigyelés és a kísérlet alkalmazásának terjedése összefügg a fogyasztó magatartásának „,kiszámíthatatlanságával”, a fogyasztó „utazásának” a vásárlási döntésig történő egyéni, fogyasztónként eltérő módjaival, az on-line és off-line eszközök egyedi kom- 
binációjával a több csatornát is tartalmazó vásárlási környezetben. Ebben a környezetben a vásárló egyéni útját részben rögzíteni lehet, részben viszont olyan váltások történhetnek, a vásárlót olyan impulzusok érhetik, amelyek megkérdezéssel kevésbé kutathatók, sokkal alkalmasabb módszer a megfigyelés, illetve a környezeti elemek változtatásának hatását nagyon eredményesen lehet kísérlettel mérni. A tudományos kutatásban mind a laboratóriumi, mind a valós bolti környezetben folytatott kísérletet gyakran alkalmazzák. A laboratóriumi kísérletben jobban lehet biztosítani a kutatást alátámasztó elmélet alkalmazását, a valós környezetben történő kísérlet nagyobb külső érvényességet biztosít (Hinz et al., 2011).

A megkérdezett, a fogyasztó által elmondott, tudatos tartalom mérése mellett egyre erósebb a törekvés a rögzíthetô, a bekövetkezett tényeken alapuló hatásvizsgálat módszereinek alkalmazására. Mivel az érzelmek a fogyasztók ingerfeldolgozásának reakciójaként értelmezhetők, így a különböző marketingingerekre adott válaszok megértése és modellezése mindig is módszertani kihívást jelentett. A rendelkezésre álló technológiák fejlődésének köszönhetően az elmúlt években felerősödött a neuromarketing, mint a fogyasztók preferenciáinak, motivációinak és elvárásainak feltárására, a fogyasztói magatartás és az egyes reklámcélú üzenetek sikerének és kudarcának meghatározására irányuló új kutatási módszer. A neuromarketing célja a neurális rendszer és a fogyasztói magatartás ,párosítása”, amelynek számos alkalmazási lehetôsége van (márkák, termékek, csomagolás, reklámozás, in-store marketing). Segítségével pontosabban körülhatárolható a vásárlási szándék, az újdonságérzés szintje, a tudatosság vagy a vizsgálat tárgyához kapcsolódó érzelmek. Bár a neurális képalkotás kvantitatív megközelítést feltételez, néhány aspektusa kvalitatív módszerekhez hasonló. A technológiai eszközök fejlődésének köszönhetóen a neuromarketing többet kínál a hagyományos kvantitatív és kvalitatív méréseknél: közvetlenül képes az agy marketingingerekre adott válaszait mérni (Varga et al., 2014). A neuromarketing az idegtudományok legfejlettebb eszközeinek felhasználásával végzett kutatások eredményeit alkalmazza, amelyek a marketingkutatásban felmerülő hagyományos etikai kérdéseken túlmenőeken új típusú problémákat is felvetnek. A neuromarketingnek a tudományos kutatásban betöltött szerepére utal, hogy a Journal of Marketing Research 2015. évi augusztusi különszámának témája a „Neuroscience and Marketing” volt, amelynek felvállalt célja, hogy mindazok a kutatások, amelyek az agyi folyamatoknak az emberi magatartásra, így a fogyasztói magatartásra is gyakorolt hatását vizsgálják, és amelyek eredményeit az elmúlt években többnyire orvosi szakfolyóiratokban publikálták, a marketinggel foglalkozó kutatók számára is ismertté váljanak (Camerer et al., 2015).

\section{A kvantitatív kutatás}

A technológiai változások következtében az adatgyújtés nemcsak felgyorsult és új csatornákon valósulhat meg, hanem a kommunikáció módja is megváltozott, a hagyományos mód helyett egyre több interaktív kommunikációra van lehetőség. Az adatok feldolgozásában is a Big data ${ }^{2}$ feldolgozási módszerei dominálnak, amelyekkel a nagymennyiségú adat feldolgozását lehetővé tevő adatbányászati szoftverek alkalmazásával az eddigi leíró kutatási célokhoz hasonló és új típusú kutatások is elvégezhetők.

A kvantitatív primer kutatásokon belül a megkérdezések jelentősége megmarad, de a tárgya jobban tud fókuszálni a fogyasztói, vásárlói attitűdre és magatartásra, az elégedettségre és lojalitásra. Az ad hoc jellegú kutatási eredmények és az adatbányászati eredmények összekapcsolása az eddiginél nagyobb lehetőséget biztosít a magatartási minták megbízható azonosítására és nyomon követésére is. Ez az elméleti kutatásoknak is nagyobb segítséget és alapot jelent, a kutatási eredmények megbízhatóbb bázist szolgáltatnak a fogyasztói magatartás és a marketingstratégiai kutatások számára.

A tudományos kutatás módszertanának fejlődése is lépést tart az átalakuló lehetőségekkel. Amennyiben a Journal of Marketing Research cikkeinek módszertanát az elmúlt időszakban áttekintjük, szembetúnő, hogy az ökonometriai modellezés, a regressziószámítási módszerek és előrejelzések száma jelentôsen nőtt. Jelen tanulmányban nem térünk ki a módszertani változások számszerúsítésére, csupán jelezni szeretnénk a tendenciákat.

A magyar tudományos kutatásban is egyre nagyobb szerepet kap a nemzetközi kutatásokban régóta alkalmazott módszertan, amely az adatokban megfigyelhető összefüggések feltárását lehetővé tevő matematikai-statisztikai módszerek alkalmazásától lényegesen különbözik abban, hogy a módszert valamilyen elméleti öszszefüggésre, konstrukcióra épülő modell esetén lehet alkalmazni. A strukturális egyenlőségek módszere, a SEM (Structural Equation Modelling) az általános lineáris modellek kiterjesztésének tekinthetó, amely párhuzamosan több regressziószámítás tesztelésére alkalmas, így segítségével egy komplexebb összefüggés modellezhető a vizsgált változók között. A SEM-modell mérési modellből (measurement model) és strukturális modellből (structural model) tevódik össze, az összefüggéseket az útdiagramban szokás ábrázolni. A mérési modellnél a módszer a megfigyelt változók és a közvetlenül nem mérhetô, látens változók közötti összefüggést állítja elő, de nem vizsgál oksági viszonyt. A strukturális modell esetében a mérési modellből kapott látens változók oksági viszonyainak vizsgálata a cél (Backhaus et al., 2011). Az elméleti összefüggésre mind 
a mérési, mind a strukturális modell megalkotásához szükség van (Hair et al., 2011). A mérési modellek a látens változók és a manifeszt változók, az indikátorok közötti összefüggéseket tartalmazzák, amely összefüggések reflektív vagy formatív típusúak. A mérési modellek tesztelése az alkalmazott skálák megbízhatósági és érvényességi vizsgálatát jelenti, szigorúan szabályozott módszertani követelmények alapján (Neumann-Bódi, 2012).

A modellekben ábrázolt összefüggések megoldására két nagy csoportba sorolható módszertant alkalmazhatunk, amelyekhez folyamatosan fejlesztett szoftverek is találhatók, elérhetők. Bármely variancia három részre bontható: a közös varianciára, az egyéni/specifikus varianciára, valamint a hibatagra. A kovarianciaalapú modellezéseknél (CB-SEM) csak a közös variancia kerül elemzésre - a kovariancia is ezen alapszik -, míg a varianciaalapú módszertannál (PLS-SEM) esetében a variancia mindhárom fajtáját vizsgálják. A megfelelő elemzési módszer kiválasztásakor tehát már azt is figyelembe kell venni, hogy fontos-e a modell szempontjából az egyéni variancia. Amennyiben ennek nincs jelentósége a CB-SEM használata kiváló megoldásnak számíthat, ellenkező esetben azonban csak a PLS-SEM alkalmazása célszerú (Kemény, 2015).

A kovarianciaalapú és a varianciaalapú modellezés inkább egymást kiegészítő eljárások, mintsem versenytársak. Jöreskog (1982) véleménye szerint a CB-SEM inkább elméletorientált, és egy átmenetet hangsúlyoz az exploratív elemzésből a konfirmatívba, míg a PLSSEM inkább ok-okozati, előrejelző/jósló szituációkban alkalmazható, amikor is a modell elég komplex, és elméletileg kevés információ áll rendelkezésre. Tehát a CB-SEM inkább elmélettesztelö, mintsem épító, míg a PLS a függó változók magyarázott varianciáját maximalizálja, ezért inkább előrejelző jellegú (Henseler et al., 2009). A varianciaalapú modellezés inkább a hipotézisek, nem pedig teljes modellek tesztelésére alkalmas, illetve alacsony szintú becslést is biztosít, így inkább a mechanizmusok megértésében segít. A legújabb kutatások mégis azt támasztják alá, hogy a varianciaalapú modellezés is alkalmas teljes strukturális modellek tesztelésére (Hair et al., 2011; Henseler - Sarstedt, 2012).

A strukturális modellben a látens változók - elméleti konstrukción alapuló - összefüggéseit vizsgáljuk, oksági összefüggések alapján. Az összefüggések direkt és indirekt hatásokat is tartalmazhatnak, lehetőség van a mediátor változók hatásainak vizsgálatára is. A modell tesztelésekor az is vizsgálható, hogy az egzogén és az endogén látens változó közötti összefüggésre hatással van-e csoportképző, moderátor változó. A strukturális modellek módszere folyamatosan fejlődő, nagyon öszszetett módszertan, a megoldására használt szoftverek közül Magyarországon is a nemzetközi kutatásokban leggyakrabban alkalmazott szoftverek terjedtek el: a CB-SEM modellek megoldására a LISREL (Jöreskog Sörbom, 1996) és az AMOS (Arbuckle, 2007) szoftverek, a PLS-SEM modellekére a PLS szoftverek (Chin, 2001) alap- és továbbfejlesztett változatai.

\section{A kutatási módszertan fejlesztési kérdéseiról}

A marketing kutatási irányairól, ezen belül a módszertani témákról is tájékozódhatunk a Marketing Science Institute által rendszeresen kibocsátott fó kutatási prioritások alapján. Amíg a 2008-2010-es kutatási fó irányok elsősorban stratégiai és fogyasztói magatartás témákat tartalmaztak és kevésbé szerepeltek direkt módszertani témák, addig a 2012-2014 közötti időszak prioritásai között közvetlen módszertani témakörök is találhatók: az adatbázisok, a Big data témaköre, a mobilplatformok és ezek hatása a fogyasztókra és a piacokra. A fogyasztói insight témakör is igen szorosan kapcsolódik a marketingkutatáshoz, továbbra is megtalálható a prioritások között, de nem új témaként, szerepelt a korábbi prioritások között is (2012-2014 Research Priorities, Marketing Science Institute).

A 2014-2016-os kutatási prioritások első csoportjában a fogyasztó és a fogyasztói tapasztalat megértése, valamint az adatgazdag környezet számára történő adatelemzés fejlesztése található. A kutatási kérdések a média új eszközeinek, a közösségi média és a digitális technológia hatásaival foglalkoznak: mennyiben változtatja meg a fogyasztó útját a vásárlási döntésig, melyek a legjobb módszerek a fogyasztó „utazásának” modellezésére? A fogyasztói döntés modellje még mindig a legjobb modellezési módszer vagy a modellezésben is más módszereket kell alkalmazni? Milyen pontokon lehet és milyen módszerrel befolyásolni a fogyasztót az új típusú utazás közben, hogyan értelmezhetó ebben az új környezetben a fogyasztói lojalitás? Milyen típusú kvalitatív és kvantitatív módszerek alkalmazhatók és hogyan kombinálhatók egymással a leghatékonyabban?

A második prioritási témakörben a marketingtevékenységek és -befektetések értékének mérése és kommunikálása, a marketingkiválóság fejlesztése és szervezése, a digitális, közösségi és mobiltechnológia elérhetóségeinek kihasználása, a tartós fogyasztói érték létrehozása és kommunikálása, valamint a teljesen integrált marketingprogramok fejlesztése és nyújtása témakörök szerepelnek. Mindegyik témakörrel kapcsolatban a mérés, a mérési módszerek és technikák új típusainak fejlesztése, illetve a meglévő́k alkalmazhatóságának lehetôségei a fó kérdések.

A harmadik prioritási témakörben a termék- és szolgáltatásinnovációval, a globális piacokkal kapcsolatos témakörökben is több kutatási kérdés merül fel, külö- 
nösen igaz ez az egyéni fogyasztók és a szervezeti vevők különbözőségeinek kutatásával foglalkozó témára, amelyben a legfontosabb kérdés a fogyasztói szegmentálás megfelelő módszerének kutatása. Ezeket a témaköröket nem ismertetjük részletesebben, de a kutatási kérdések között több, a marketingkutatáshoz erôsen kapcsolódó kérdés található (Marketing Science Institute, 2014-16 Research Priorities).

\section{Várható tendenciák a gyakorlati marketingkutatásban}

A gyakorlati piackutatásban a hatások mérése helyett vagy mellett fontos szerepet kaphatnak a sikerességi mutatók és kutatások, vagyis nemcsak az intézkedések hatásosságának a mérése (márkaismertség, imázs, fogyasztói elégedettség), hanem a ráfordított költségek pénzügyi hatásainak, sikerességének mérése is fontossá válik, kiemelten a marketingintézkedések ROI-ra gyakorolt hatása (Fischer, 2013).

Felmerül a kérdés, hogy a vállalati adatok egyre inkább helyettesíthetik-e a piackutatási adatokat? Hagyományosan a piackutatás hidat képez a vállalat és a fogyasztó, a vásárló között, a CRM megjelenése és különösen az interneten rendelkezésre álló lehetőségek ezt a távolságot részben betöltik, áthidalják. A vállalat és a vásárló közötti interakció direktebbé válik: a visszacsatolásokat, az információkeresési és vásárlási szokásokat közvetlenül rögzítik és így értékelhetők lesznek. A vállalaton belül rendelkezésre álló adatbázis, a Big data nemcsak elemzést, hanem az intézkedések és hatásuk összekapcsolását is lehetôvé teszi. Nagyon fontos kérdés: a piackutatás teret veszít ezáltal, vagy éppen lehetővé válik a módszertani tudást, tapasztalatot a vállalati adatbázisok értékelésében hasznosítani?

Az adatokat használni vagy generálni kell-e? A Big data olyan adatmennyiség, amire eddig nem volt példa, amelyben megjelennek mind aggregált, anonim adatok, mind az egyéni fogyasztó szintjén nem anonim adatok. Mivel a fejlődés még a kezdeti fázisban van, előre alig belátható, milyen adatmennyiség fog rendelkezésre állni a „folyamatosan on-line lenni” törekvés következtében, amelyet a technikai eszközök széles skálája fog lehetôvé tenni, mint az egyes használati tárgyak (autó, a lakásban levő készülékek) hálózatba kapcsolása, a testen viselhetô eszközök, mint óra, szemüveg, karkötők hálózatba kapcsolása. Az egyes nagy cégek, amelyeknél a nagy adatbázis képződik, mint a Google, a Facebook, az Amazon együttmúködése a fogyasztó behálózottságát és így a róla tárolódó adatbázis méretét nagyban növelik.

Anonimitás vagy interakció? A hagyományos piackutatásban az anonimitás alapkövetelmény volt, az adatbázisokban azonban fogyasztói szintú, nem anonimizált adatok is rendelkezésre állnak. Amenynyiben ezeket az adatbázisokat a marketing céljaira a marketingkutatás eszközeinek alkalmazásával felhasználják, akkor megkérdőjeleződik a piackutatás egyik hagyományos értéke. Ugyanakkor a személyes adatokkal ellátott fogyasztói információk a vállalatok számára több előnyt is jelentenek: megkönnyítik a közvetlen visszacsatolásokat a fogyasztóhoz, például a panaszkezelést.

Insourcing az outsourcing helyett? A kutatási eszközök standardizálási tendenciája lehetőséget ad arra, hogy a megbízói oldalon a vállalati piackutatók ezeket a standardizált eszközöket, szoftvereket maguk múködtessék, így a kutatási tevékenység egy része az insourcing irányba tolódhat el, vagyis átkerül a szolgáltatói oldalról a megrendelői oldalra.

Az ügyfelek elérése mint szúk keresztmetszet: a potenciális megkérdezettek korlátozott elérhetősége növekvő problémát okoz a minták reprezentativitásában. Mindezt bizonyos jogi tisztázatlanságok is nehezítik, a direkt marketing és a piackutatás elhatárolhatóságának problémája továbbra is fennáll, valamint egyes esetekben engedélyhez kötött a megkérdezettek elérése, mindez nehezíti az elérhetőséget. A felmerülő kérdések: hogyan lehet a megkérdezettek motiváltságát megórizni, illetve növelni, valamint a panelépítés és az egyes válaszadói közösségek építésének lehetőségei, milyen alternatívái lehetnek a klasszikus mintavételi módszernek, illetve mennyiben használhatók a megkérdezés helyett a meglevő adatbázisok?

A mobil behálózottság jelenti-e azt, hogy a megkérdezést mindig, mindenhol le lehet folytatni? A folytonos behálózottság, a „mindig on-line” elérhetôség új megkérdezési lehetóségeket is kínál: rövidebb megkérdezés a POS-helyen, amikor a megkérdezett éppen az adott bolti környezetben tartózkodik, illetve a megkérdezettek a hagyományostól eltéró módon és szituációban érhetôk el: ezek új lehetôségek.

A fenntarthatóság a politikai és társadalmi szlogenek szintjéról egyre inkább beépül a vállalatok cél- és eszközrendszerébe, vagyis ennek is felmerül a mérhetősége, különösen a hatásokra vonatkozóan. Ez egy sor új mutatószám kidolgozásának igényét veti fel, amiket a piackutatásnak kell kialakítania.

\section{A marketingkutatás jövőjének kihívásai és lehetőségei}

A következő húsz évben többféle tendencia jellemezheti a piackutatást, amelyekből a két szélsőséges nézetet vázoljuk fel:

A legpesszimistább szcenárió: a hagyományos piackutatás már „kiöregedett”, a Big data időszakában a vállalatok megpróbálták az ügyfeleket és a piacokat 
maguk megfigyelni és az adataikat kezelni. Ma ez már automatikusan történik: az információ, a cselekvés és a reakció össze van kötve egymással és a piackutatás olyan felesleges alkatrésszé vált, mint a motorolaj az elektromos autóban.

Az optimista szcenárió: a piackutatás soha nem játszott ekkora szerepet az értékalkotásban, mint ma: a technikai fejlődés és a digitalizáció soha nem látott mértékben növelte meg a kutatási témákat és a kutatási lehetôségeket. Az egyre professzionálisabban múködő vállalatok az egyre kiterjedtebb piacokon, egyre több adatot és mutatószámot, valamint szakembert és insight-ot igényelnek. Ezen igényeknek csak egy virágzó, egyre innovatívabb piackutatási ágazat felelhet meg!

Ha azt a dilemmát nem is tudjuk megválaszolni, hogy melyik szcenárióhoz, mekkora valószínúségeket kapcsolhatunk, a gyakorlati piackutatást jelenleg jellemző adatokból nyerhetünk betekintést a gyakorlat tendenciáiba.

A piackutatási piac átalakulása történik az egész világon, a piac egészére vonatkozóan látszanak változások, de az igények drámai csökkenése, vagyis a piackutatás lefelé ívelő tendenciája nem látszik. Az ESOMAR adatai azt mutatják, hogy világméretben nem csökken a piackutató piac mérete, de az egyes régiókban eltérőek a tendenciák, Európában jelentốs a csökkenés. A megváltozott ügyféligényekre jellemző egyrészt az igények jelentős növekedése a közösségi média elemzése és Big data elemzése területén. Jelentôs igénynövekedés várható a mobileszközös kutatásban, bár egyelőre a kutatók adják a hajtóerôt, amit várhatóan az ügyfelek igénye is követni fog.

A piackutatási iparban a szereplők is változnak, ami részben a piac átrendeződésével is jár. A szakmai felmérések szerint a Google az ötödik leginnovatívabb kutatócég a TNS és Millward Brown előtt, jelentős szerephez kezdenek jutni a Big data elemzésére épülő adatelemzó és tanácsadó cégek. Az egyik legdinamikusabban növekvő kutatócég a TESCO tulajdonú DunnHumby, ugyanakkor vannak olyan vélemények, amelyek szerint a TESCO hanyatló piaci teljesítményének egyik oka a Big data elemzések egyoldalú és kizárólagos figyelembevétele a döntésekben.

A módszertanban nem történt még áttörés, bár divatirányzatok mindig vannak, például a kutatási célú közösségek alakulása, amelyek azonban általában rövid életúek, mert a legtöbb esetben nem történik meg a megfeleló utógondozás. Az új on-line kvalitatív kutatási módszerek nem értek el áttörést, a hagyományos technikák még a helyükön vannak, pedig drágábbak az on-line módon végzettekhez képest (Mészáros, 2014).

A piackutatási ipar éves növekedési üteme 2013ban nem jelzi a jelentős csökkenést, de az egyes régiók eltérő tendenciát mutatnak, míg az éves ütem $0,7 \%$-os növekedés, ezen belül Európában 1,4\%-os a csökkenés, Észak-Amerikában 2,9\%-os növekedés, Ázsiában 1,6\%-os növekedés, Afrikában és Közel-Keleten mintegy $1 \%$-os csökkenés tapasztalható.

Az 1. táblázat a piackutatás növekedési ütemét mutatja az elmúlt öt évben világméretben.

1. táblázat

\section{A világ piackutatásának növekedési üteme az elmúlt öt évben}

\begin{tabular}{|c|c|c|}
\hline Időszak & $\begin{array}{c}\text { abszolút növeke- } \\
\text { dési ütem (\%) }\end{array}$ & $\begin{array}{c}\text { nettó növekedési } \\
\text { ütem* (\%) }\end{array}$ \\
\hline $2009 / 2008$ & $-3,7$ & $-4,6$ \\
\hline $2010 / 2009$ & 5,2 & 2,8 \\
\hline $2011 / 2010$ & 3,8 & 0,4 \\
\hline $2012 / 2011$ & 3,2 & 0,7 \\
\hline $2013 / 2012$ & 2,8 & 0,7 \\
\hline \multicolumn{3}{|c|}{ *: az inflációval korrigált adat alapján } \\
Forrás: ESOMAR éves jelentés 2014
\end{tabular}

A piackutatás határait elmossák az új technológiai alapú adat-, tudás- és információszolgáltatások. A teljes piacnagyságot 65 milliárd dollárra becsülik, amelyból 12,5 milliárdot az új módszerek és technológiák tesznek ki.

Az adatokból az igen szerény mértékú növekedés látszik, de a piackutatás „elhalása” nem. A piackutatással foglalkozók mind a tudományos kutatásban, mind a gyakorlati munkában reménykedhetnek az optimista szcenárió megvalósulásában, illetve a reménykedésen túlmenően tehetnek is érte. Erre vonatkozóan Malhotra (2001) útmutatása egy lehetséges cselekvési alternatívaként is interpretálható: „Az új évtizedbe belépve, a marketingkutatás nagy ígéreteket jelenthet. Ahhoz, hogy az ígéretek, a marketingkutatásban meglevő lehetóségek realizálhatók legyenek, a legfontosabb, hogy a tudományos és a gyakorlati marketingkutatás közötti szakadék áthidalásra kerüljön. Ez történhet részben úgy, hogy a tudományos kutatók olyan témákkal foglalkoznak, amelyek a vállalati vezetők számára releváns témák. Ezzel egyidejúleg a gyakorlati piackutatásban dolgozóknak fel kell ismerniük az elméleti megalapozottság jelentőségét és nagyobb hangsúlyt kell fektetniük az elméleti követelményekre és eredményekre. Az elmélet ugyanis lehetővé teszi, hogy a saját jelentős eredményeinket összehasonlítsuk és integráljuk korábbi kutatási eredményekkel. A tudományos és a gyakorlati kutatás kölcsönös befolyásolására van szükség." 


\section{Lábjegyzet}

'A tanulmány felhasznál részeket a következő kötetből: Simon J. (2012): Új tendenciák a marketingkutatásban. in: A marketing új tendenciái. A Széchenyi István Egyetem Kautz Gyula Gazdaságtudományi Kar és a Regionális- és Gazdaságtudományi Doktori Iskola szervezésében megrendezésre kerülő konferencia kiadványa, Győr: p. 23-34.

${ }^{2}$ A „Big data” kifejezés általában a nagy adatbázisokra vonatkozik, értelmezése nem egységes. A dolgozatban a következő meghatározást fogadjuk el: „A Big data olyan nagyméretű adatbázis és elemzési technikák öszszefoglaló meghatározása, amelyek olyan nagy méretúek és komplexek, hogy kezelésükhöz speciális és fejlett adatelemzési eszközök, adattárolási technikák és ábrázolási módszerek szükségesek” (Chen et al., 2012).

\section{Felhasznált irodalom}

Arbuckle, J.L. (2007): AMOS 16.0 User1s Guide, SPSS

Backhaus, K. - Erichson, B. - Weiber, R. (2011): Fortgeschrittene Multivariate Analysemethoden. Berlin-Heidelberg: Springer

Bacon, L. (1999): Data mining in Marketing. in: AMA Conference, Atlanta

Brinberg, D. - Hirschmann, E. C. (1986): Multiple Orientations for the Conduct of Marketing Research: An Analysis of the Academic/Practitioner Distinction. Journal of Marketing, Vol. 50, No. 4 (Oct, 1986): p. 161.

Brown, S. (1995): Postmodern marketing. London: Routledge

Camerer, C. - Yoon, C. (2015): Introduction to the Journal of Marketing, Research Special Issue on Neuroscience and Marketing. Journal of Marketing Research

Chin, W. W. (2001): PLS User's Guide

Deshpandé (1983): „Paradigms Lost”: OnTheory and Method in Research in Marketing, Journal of Marketing, Vol.47, Fall 1983: p. 101-110.

Eisenhardt, K.M. (1989): Building Theories from Case Study Research. The Academy of Management Review, Vol. 14, No. 4 (Oct, 1989): p. 532-550.

Eisenhardt, K. M. (1991): Better Stories and Better Constructs: The Case for Rigor and Comparative Logic. The Academy of Management Review, Vol. 16, No. 3 (Jul., 1991): p. 620-627.

ESOMAR (2014): Annual Research Report

Fischer, M. - Wagner, N. - Albers, S. (2013): Investigating the Performance of Budget Allocation Rules: A Monte Carlo Study. Marketing Science Institute Report: p. 13-114.

Fojtik, J, (1999): Marketing a posztmodern globalitásban. Marketing és Menedzsment, 6: p. 66-72.

Fojtik, J. (2006): A marketing újragondolásának lehetőségeiről - „Rethinking Marketing”. Marketing és Menedzsment, 5-6.: p. 4-9.

Glaser, B. G. - Strauss, A. L. (1967): The discovery of grounded theory. Strategies for qualitative research
Hair, J. F. - Black, W. C. - Babin, B. J. - Anderson, R. E. - Tatham, R. L. (2011): Multivariate data analysis (vol. 5). New York: Pearson Prentice Hall

Hakansson, H, (1982): Industrial marketing and our chases of industrial goods: an interaction approach. Chichester: Wiley

Henseler, J. - Ringle, C. M. - Sinkovics, R. R. (2009): The use of partial least squares path modeling in international marketing. Advances in International Marketing, 20: p. 277-319.

Henseler, J. - Sarstedt, M. (2012): Using Partial Least Squares Modeling in International Advertising Research: Basic Concepts and Recent Issues. in: Handbook of Research on International Advertising: p. 252-272.

Hinz, O. - Hann, I. H. - Spann, M. (2011): Price Discrimination in E-Commerce? An Examination of Dynamic Pricing in Name-Your-Own-Price Markets. MIS Quarterly, Vol. 35(1)

Horváth, D. - Mitev, A. (2015): Alternatív kvalitatív kutatási kézikönyv. Budapest: Alinea Kiadó

Jackson, R. - Wang, P. (1994): Strategic Database Marketing. London: NTC Publishers

Jöreskog, K. G. - Sörbom, D. (1982): Recent Developments in Structural Equation Modeling. Journal of Marketing Research, Vol.19, No.4: p. 404-416.

Jöreskog, K. G. - Sörbom, D. (1996): LISREL 8 User's Reference Guide. SSI International

Kemény, I. (2015): A versenytársak csak egy kattintásra vannak - Az újravásárlási szándék és szájreklám alakulása az elektronikus szolgáltatásminőség és elégedettség tükrében az e-kereskedelem esetében. PhD-diszszertáció. Budapest: Budapesti Corvinus Egyetem

Kozinets, $R$. V. (2002): The field behind the screen: using netnography for marketing research in online communities. Journal of Marketing Research, 39(1): p. 61-72.

Kröber, A. - McMichael, L. (2008): Qualitative Sampling Methods, A Primer for Technical Communicators. Journal of Business and Technical Communication, Vol. 22, Number 4: p. 454-473.

Malhotra, N. K. - Peterson, M. (2001): Marketing research in the new millenium: emerging issues and trends. Marketing Intelligence \& Planning, 19/4: p. 216-235.

Malhotra, N. K. - Simon, J. (k.m.) (2009): Marketingkutatás. Budapest: Akadémiai Kiadó

Marketing Science Institute (2012): 2012-2014 Research Priorities

Marketing Science Institute (2014): 2014-2016 Research Priorities

Mészáros, J. (2014): Modern módszertanok a piackutatásban. Előadás az Országos Marketing Konferencián 
Moore, K. - Burbach, R. - Heeler, R. (1995): Using neural nets to analyze qualitative data. Marketing Research, Vol. 7, Winter: p. 34-39.

Neumann-Bódi, E. (2012): Vevőértékelés egyéni és szervezeti vásárlók esetében - Az ajánlással szerzett ügyfelek jellemzői és hatásuk a vevőértékre szervezetközi viszonylatban. PhD-értekezés. Budapest: Budapesti Corvinus Egyetem

Palmquist, J. - Ketola, L. (1999): Turning Data into Knowledge. Marketing Research, Vol. 11, Issue 2: p. 29-32.
Richards, L. (1999): Using NVivo in Qualitative Research. Thousand Oaks, CA: Sage Publications

SCOLARI (2000): http://scolari.com

Simon, J. (2015): Nemzetközi piackutatás. in: Rekettye, G. - Tóth, T. - Malota, E. (2015): Nemzetközi marketing. Budapest: Akadémiai Kiadó

Varga, A. - Simon, J. - Horváth, D. - Pintér, A. (2014): Az érzelmek és az agy - fókuszban a neuromarketing kutatás. Előadás MOK konferencián

Yin, R. (1984): Case srudy research: Designs and methods. Beverly Hills, CA: Sage Publishing 